\title{
Engaging Old Testament prophetic literature in traumatic times of loss and grief
}

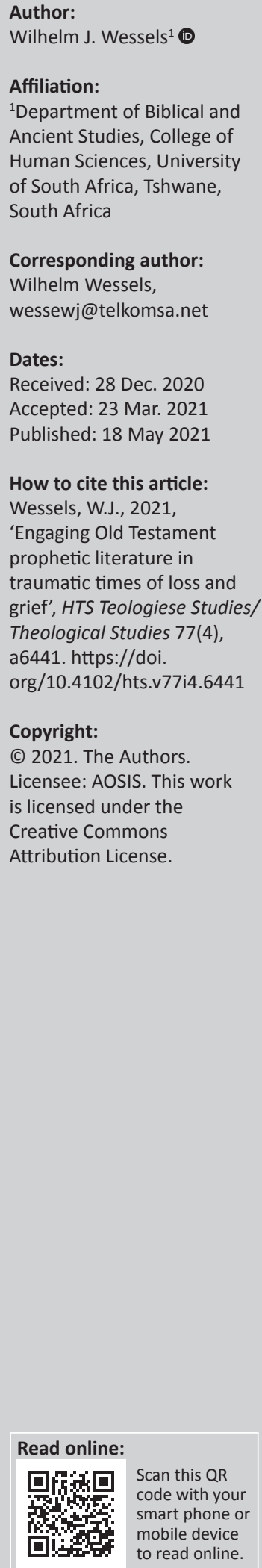

This article addresses not only the matter of loss and grief but also hope and recovery. The coronavirus disease 2019 (COVID-19) has hugely affected not only South Africans but also people globally. One of the key features of this pandemic is loss and the associated grief. To explore these topics, the author has engaged prophetic literature, more specifically the books of Isaiah and Jeremiah, which present compelling cases of loss and grief. An attempt was made to identify similarities between the experiences of the people of Judah and our current experiences of loss and grief because of the pandemic. Whilst the reality of loss and grief is validated, the positive role of prophetic words of comfort and hope is also valued.

Contribution: This article offers original research in the field of biblical studies, more specifically, in the field of the Old Testament. This is in line with the scope of the article aims at relating texts from the prophetic literature to a current challenging situation of grief and loss because of the COVID-19 pandemic.

Keywords: COVID-19; loss; grief; emotions; exile; comforting; hope; recovery.

\section{Introduction}

If ever there was a challenging time for our generation, 2020-2021, with the coronavirus disease 2019 (COVID-19) is the real deal. Most people in the world, in some way or other, have been affected by this pandemic. Only the future will tell how severe and far-reaching the after-effects of this pandemic will be. Many people say that this pandemic has changed our world so profoundly that nothing will ever be the same again. It is not possible, at this stage, to determine the real impact of COVID-19 on countries, work environments, economies and our social lives; however, we are already experiencing some of in various aspects of our lives. These aspects are the more obvious indicators that confirm the impact of the COVID-19 pandemic, it is, however, the more hidden aspects, namely the social and psychological effects that will only show as time passes, which may require intervention in the long term.

What we are experiencing currently is quite unique, the closest to this, perhaps, is the 1918-1919, so-called, Spanish influenza (cf. Barro, Ursúa \& Weng 2020:1-26). There are many examples of people who have experienced life-changing disasters and events, for instance, natural disasters such as hurricanes, floods, fires, plane crashes and various other forms of disasters-and, no doubt, these events have impacted lives in many different and disastrous ways. In recent times, we have also seen many displacements of people because of wars and the destabilising conditions in countries affected by wars, such as political and social turmoil, which have compelled people to seek refuge in other states for safety and, possibly, better living conditions.

Within the context of religious experiences, there are many examples of displacements of people because of religious persecutions or the lack of opportunities to experience freedom of religious expression. In our own South African context, we have the example of the French Huguenots, who came to South Africa because of religious intolerance and persecution in France in the 17th century (Giliomee 2012:11).

With the outbreak of the COVID-19 pandemic, perhaps, one of the basic aspects that have affected most people in the world, also in the South African context, is the infringements on freedom. With the commencement of lockdown and other measurements undertaken by governments to curb the spread of COVID-19 pandemic, people suddenly became aware of how all these measures impact their freedom. With lockdown in South Africa, the government has decided to limit the freedom of movement and association, social interactions with people and even choices regarding

Note: Special Collection: From timely exegesis to contemporary ecclesiology: Relevant hermeneutics and provocative embodiment of faith in a Corona-defined world - Festschrift for Stephan Joubert, sub-edited by Willem Oliver (University of South Africa). 
food and clothing. And, although initially there was broad support for these measures, as time progressed, the support waned as the restrictions on freedoms became real. Lockdown has become synonymous with lack of freedom, lack of choice and lack of association.

The people of Israel and Judah had their own experiences of displacement and the equivalent experience of a lockdown. In $721 \mathrm{BCE}$, the northern Kingdom of Israel was invaded by the Assyrian Empire. In the process, the people of this kingdom were taken into exile, with far-reaching consequences for their existence, future and their history. At the time of the dominance and threat posed by the Assyrians, the prophet Isaiah had to deal with the immense effect of the displacement of the people of Israel and the ensuing threat to Jerusalem and the southern Kingdom of Judah (Tull 2010:9-11). As history progressed, the Assyrian Empire was displaced by the Neo-Babylonian Empire, who, for quite some time, dominated the political scene, affecting the people of Judah. Two of the major events that took place, at this time, are the exile of the Judean people, first in 597 and then again in 586-587 BCE. This had the effect of the displacement of people to a foreign country and an eventual lockdown so to speak, in Babylonia (Thompson 1980:22-27).

In this article, the objective is to engage the prophets of the Old Testament, in particular, Isaiah and Jeremiah, in relation to our current context of being affected by the COVID-19 pandemic and its enormous emotional and psychological effect on people. The aim is to look at similarities in experience and how the prophets of the time addressed the people of Yahweh in comforting them and creating hope for the future. This I will do by choosing a selection of passages from the prophetic literature that seem relevant. From the knowledge gained from a close reading of these passages, some parallels will be drawn to our common experiences of emotional distress, lack of freedom and hope of surviving the challenges posed by the COVID-19 pandemic.

\section{Contextual aspects pertaining to the books of Isaiah and Jeremiah}

In terms of the history that forms the background of the book of Isaiah, it covers the period of the Assyrian domination, the Neo-Babylonian period and the return from the Babylonian exile. With this in mind, the book is traditionally divided into three sections, namely Isaiah 1-39, 40-55 and 56-66, with each major section broadly relating to the three mentioned periods. At the end of chapter 39, the following important conversation takes place between King Hezekiah and the prophet Isaiah. In 39:5-7, the following is stated:

${ }^{5}$ Then Isaiah said to Hezekiah, 'Hear the word of the LORD of hosts:

${ }^{6}$ Days are coming when all that is in your house, and that which your ancestors have stored up until this day, shall be carried to Babylon; nothing shall be left, says the LORD.

7 Some of your own sons who are born to you shall be taken away; they shall be eunuchs in the palace of the king of Babylon'. (New Revised Standard Version- NRS)
It is evident, from this passage, that the prophet indicates that the Assyrian dominance is about to come to end and that the new world power, to be reckoned with in future, is the Babylonian Empire. The future of the kingship is in jeopardy (Tull 2010:558).

If we turn to Isaiah, chapter 40 commences with two consecutive plural imperatives instructing that the people of Elohim should be comforted. They should be comforted by the message that the Babylonian exile is about to end and therefore circumstances will change for the better for both the exiles and for those who have remained behind in Jerusalem. The message of Isaiah 40 and following chapters is that a new beginning for the people of Judah is imminent, there is therefore hope for the future (Berges 2012:303). The implication of this is that between the prophetic announcement to King Hezekiah, in chapter 39, of the future involvement of the Babylonian Empire in the affairs of the southern Kingdom and the situation addressed in chapter 40 onwards, a great deal has transpired in the history of Judah that have not been covered in the book of Isaiah. This is where the book of Jeremiah comes in. The thought, nowadays, is that this second part of the book of Isaiah $(40-55)$ is a revision of material in the sixth century, but the historical backdrop is the Babylonian period, with its impact on those exiled to Babel as well as those who remained in Judah and Jerusalem (McEntire 2015:77).

If one turns the attention to the book of Jeremiah, it is evident that the historical background that is displayed concerns the threat by the Babylonian Empire and the eventual occasions of exile of the people of Jerusalem and Judah. According to the book of Jeremiah, the prophet acted during the time of Babylonian dominance and interference in the affairs of the Judean people, followed by the threat and besieging of Jerusalem and the exile of the people, first in 597 and also 586-587 BCE, to Babylon. So, in essence, what it boils down to, is that the book of Jeremiah, in terms of history, fits between Chapters 39 and 40 of the book of Isaiah.

\section{How can this period be characterised?}

This question of what happened in relation to events between Isaiah 39 and 40, as reflected in the book of Jeremiah, is an attempt to probe what the ordinary people experienced in this time of turmoil and displacement (Petersen 2015:17). How did they respond to the challenges as far as we can determine that from the analysis of the text tradition we have in the prophetic literature? Similarly, the question could be applied to the current situation globally: What are the emotional effects on the people of today whilst they are experiencing various crises? These are important questions to be asked in terms of our interest in establishing points of similarity to our current COVID-19 crisis: How do we relate to what is displayed in the prophetic literature and what insights can we gain that will help us to cope with our current challenges? 
An important matter that should be acknowledged is that the world history transpiring in the international arena at the time of the existence of Israel and Judah, affected them both politically and socially. The Hebrew text is a testimony of how the political reality of the time was processed in terms of their understanding of God. What we have in the text is the religious interpretation of the effect of the external political events on their relationship with Yahweh, the covenant God. On the political level, the domination and exile of the people of Judah were the result of power politics and empire building by the Babylonians. On the religious level, in Judah, the exile was seen as the result of the breaking of the covenant stipulations; therefore, disloyalty to Yahweh (cf. Cronjé \& Mullins 2011:98 also in this regard).

\section{A time of loss}

First and foremost, this period in the history of Judah can be typified as a time of immense loss. In 609 BCE, King Josiah died in battle with the Egyptians. This was a huge loss in terms of the kingship and the religious reforms he was putting in place to restore the relationship of the Judeans with the covenant God. With the Babylonian Empire coming to power, a series of deportations followed with devastating consequences. One major such displacement was the exile of King Jehoiachin with enormous implications for the Davidic kingship (Nelson 2014:143,171). This is the message, according to Jeremiah 22:24-30, to King Jehoiachin, in 597 BCE:

${ }^{24}$ As I live, says the LORD, even if King Coniah son of Jehoiakim of Judah were the signet ring on my right hand, even from there I would tear you off

${ }^{25}$ and give you into the hands of those who seek your life, into the hands of those of whom you are afraid, even into the hands of King Nebuchadrezzar of Babylon and into the hands of the Chaldeans.

${ }^{26}$ I will hurl you and the mother who bore you into another country, where you were not born, and there you shall die.

${ }^{27}$ But they shall not return to the land to which they long to return.

${ }^{28}$ Is this man Coniah a despised broken pot, a vessel no one wants? Why are he and his offspring hurled out and cast away in a land that they do not know?

${ }^{29} \mathrm{O}$ land, land, land, hear the word of the LORD!

${ }^{30}$ Thus says the LORD: Record this man as childless, a man who shall not succeed in his days; for none of his offspring shall succeed in sitting on the throne of David, and ruling again in Judah. (NRS)

King Jehoiachin and his mother were taken into exile by King Nebuchadnezzar in 597BCE, never to return to his land of birth. More than that, it is said that there will no longer be a king in the line of David to sit on the throne in Jerusalem. This implies a loss of kingship, a loss of land and the loss of descendants - a bleak future of loss. In Jeremiah 39, the second occasion of exile is described, with the invasion of Jerusalem, in 586-587 BCE, when King Zedekiah was captured, Jerusalem invaded and the palace and the houses of people set on fire (cf. Nelson 2014:143). According to
Jeremiah 39:10, the commander, Nebuzaradan, left behind the poor people and gave them the vineyards and the fields. The strategy of the Babylonians was to weaken the land of Judah by taking away the leaders, also the people with skill, the artisans and the educated people such as the Zadokite priests (Brueggemann 2010:2-3). They left behind the poor and unskilled people, who were in no position to pose a threat to the Babylonian Empire (cf. Sharp 2019:94).

What all of this implies is that for the people, who went into exile, there was a loss of freedom, loss of their city and land, loss of a place of worship- that is the temple- and a separation from friends and families. There was also a loss of religious stability, in the sense that they had to redefine their understanding of Yahweh's presence that was believed to be in the temple as earthly abode. In the foreign country, they had to oblige to what was offered to them by their Babylonian overlords.

It was not only the people in Babylonian exile who experienced severe loss, those who remained behind in Jerusalem and Judah were left leaderless, poor and powerless. Their loss also implied segregation from family and friends, no King in the lineage of David and a destroyed temple. They were placed under the supervision of a governor, appointed by the Babylonian regime, which implied at loss of what the future had held in store for them. The establishment in Jerusalem lost their confidence, resulting in grief and mourning (Brueggemann 2010:33).

Our own experiences of loss might assist us to relate to the loss that the people of Judah experienced in their time of 'lockdown', both in a foreign country, but, in a sense, also for those who were left behind in Judah, as disempowered people in their own country. We have all experienced some form of loss in this time of the pandemic, in 2020 and 2021. The degree of loss might differ, but in the lockdown period, because of the pandemic, we have all faced loss. These include loss of freedom and movement, the freedom of choice, loss of family contact (with parents or with children), loss of communal worship and socialising. Then the more dire forms of loss such as job losses, ${ }^{1}$ loss of income and all that result from that and, most challenging, the loss through death of loved ones. In many instances, people were not allowed to spend their final moments on earth with their loved ones. The COVID-19 pandemic has without a doubt impacted people's mental health. Frissa and Dessalegen (2020:1) had observed in sub-Saharan Africa that 'Health care workers, patients with COVID-19 and other illnesses, children, women youth and the elderly are experiencing post-traumatic stress disorders, anxiety, depression and insomnia'. Naidu (2020:559) also acknowledged these mental health aspects in the South African society but adds the

1.In a study on the impact of the hard lockdown in South Africa between February and April 2020, Jain et al. $(2020: 19)$ observed a 40\% decline in active employment They April 2020, Jain et al. (2020:19) observed a 40\% decline in active employment. They concluded 'we estimate that $20 \%-33 \%$ of those who have lost jobs over the lockdown period fell into poverty, which translates to between and 1.7 million joblosers. Accounting for dependents, we tentatively estimate that between 3 and 5.5 million individuals fell into poverty as a result of this job-loss'. With the relaxing of the lockdown from level 5 to level 3 matters have improved, but it is still challenging for many households. 
occurrence of gender-based violence and child abuse. With all these forms of loss, strong emotions transpired.

\section{A time of raw emotions and trauma}

Two short verses in the book of Isaiah, as an example, give expression to loss the people of Judah has experienced. These verses reveal that the people are questioning not only Yahweh's loyalty and ability to act on their behalf but also his willingness to act to change their situation (Oswalt 1998:303). These verses read:

Isaiah 40:27 Why do you say, O Jacob, and speakO Israel, 'My way is hidden from the LORD, and my right is disregarded by my God'?

Isaiah 49:14 But Zion said, 'The LORD has forsaken me, my Lord has forgotten $\mathrm{me}^{\prime}$.

The people of Judah believe that Yahweh has rejected them and has lost interest in their plight. They even blamed himaccusing him of abandoning them. The question to ask is, how does the prophet Isaiah respond to their questioning and doubt?

\section{Isaiah's response in Chapters 40 and 49}

In both Chapters 40 and 49 , Zion is addressed. The importance of this is the good news the prophet is announcing to the exiles and also to those who have remained in Jerusalem and Judah, that Yahweh will return to Zion, as his dwelling place of choice (Sharp 2019:56) and, with him, also the exiles (Goldingay 2014:114). It is important to realise that the Zion lamenting Yahweh's neglect and non-remembrance of them 'is the corporate entity that the prophet imagines lamenting, the entity that exists as a person independently of the people who happen to live there at a particular moment' (Goldingay 2014:114). It is evident from both Isaiah 40:27 and 49:14 that the exiles were struggling to come to terms with their situation and were concerned that Yahweh's care for them no longer existed (Boda et al. 2015:51).

Isaiah 40:1-31 can be subdivided into several subsections, namely 40:1-11 -announcing the good news that Yahweh is there for his people like a shepherd to comfort his people; 40:12-26 -showing Yahweh's greatness and power through the creation (Blenkinsopp 2002:4); and 40:27-31 -announcing Yahweh as the one who takes care of the weak and the weary (Oswalt 1998:43, 56, 70). Isaiah 49:1-26 can be subdivided into 49:1-7- concerning the calling off the Servant; 49:8-13 reveals what the Servant will be doing; 49:14-23-speaking of the restoration of the children of the nation in Zion and finally, 49:24-29-announcing the destruction of the oppressors (Barker 2003:531-532; Oswalt 1998:285, 295, 301, 312).

As explained, following the announcement of a future invasion by the Babylonians in Isaiah 39, Jeremiah forms the connection, as far as historical events are concerned, to chapter 40 onwards, when the Babylonian exile became a reality. What is interesting, following the reality of Babylonian exile, is the introduction in Isaiah 40:1 with the command that the people of Judah should be comforted. What then follows is a long description of who Yahweh is, his power and might and his gentle care for his people, like 'a shepherd' (40:11). The prophet goes to great lengths to testify about the greatness of Yahweh and his Spirit. This he does by referring to Yahweh's greatness embodied by nature and the work of his hands (cf. 40:12). He continues by saying that nobody and nothing can be compared with him, not the nations, who are nothing and worthless before him, nor the idols (40:17, 18, 19-20). The prophet's powerful testimony reaches a crescendo with the following address in chapter 40:

${ }^{21}$ Have you not known? Have you not heard? Has it not been told you from the beginning? Have you not understood from the foundations of the earth?

${ }^{22}$ It is he who sits above the circle of the earth, and its inhabitants are like grasshoppers; who stretches out the heavens like a curtain, and spreads them like a tent to live in;

${ }^{23}$ who brings princes to naught and makes the rulers of the earth as nothing.

${ }^{24}$ Scarcely are they planted, scarcely sown, scarcely has their stem taken root in the earth, when he blows upon them, and they wither, and the tempest carries them off like stubble.

${ }^{25}$ To whom then will you compare me, or who is my equal? says the Holy One.

${ }^{26}$ Lift up your eyes on high and see: Who created these? He who brings out their host and numbers them, calling them all by name; because he is great in strength, mighty in power, not one is missing. (NRS)

The purpose of all this is to instil trust in Yahweh and to counter any complaints, doubts and discontent from the people of Judah (Brueggemann 2010:64). The poet prophet, voicing Yahweh's words, felt the need to elaborate on the foundations of faith in Yahweh, in Isaiah 40:1-26, in order to address the discontent of Judah's people (Goldingay \& Payne 2006:125). With this powerful speech of who Yahweh is, is the prophet tone-deaf for the expression of the strong emotions and strong feelings of the people? It is evident, from what follows in this chapter, that the prophet was aware of the emotions that accompanied their situations of loss. The prophet responds by quoting the words of the people, in 40:27:' Why do you say, my way is hidden from the LORD; my cause (judgement) is disregarded by my God?' Whereas the recipient of the oracle thus far was Zion, as a collective term, in verse 27, Jacob and Israel are addressed. As Goldingay and Payne (2006:125) stated, ‘We assume that empirically Jacob-Israel denote the Judean refugees in Babylon, and that describing them as Jacob and Israel imply a theological claim for that refugee community'. The Judeans are dissatisfied because they experience that Yahweh is not taking notice of their plight and communication has broken down (Blenkinsopp 2002:194). The two concepts

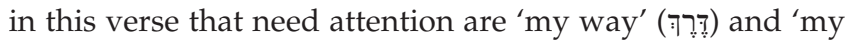

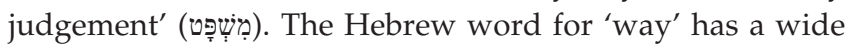
range of possible meanings, but, in this context, it seems to mean 'condition' or 'situation' (Lim 2010:43). Goldingayand 
Payne (2006:126) argued that the reference to 'my justice' implies that Yahweh has failed to use his 'decisive authority' on their behalf. Oswalt (1998) had a slightly different understanding of the meaning of 'my justice'. The complaint, in his view, is that God 'either does not know or does not care about what is right concerning Israel' (Oswalt 1998:72). In essence, it boils down to Judah's complaint that Yahweh has failed to uphold their 'right' as his people. As his people, they expected that he will take care of them and protect them. However, it seems that he has lost sight of their plight and has abandoned them. Clearly, the prophet did not agree with them, but those were their honest sentiments of the people.

The question is, did they have reason to be dissatisfied? They have experienced the exile, they are displaced and they have experienced severe losses; thus, in their minds, there is more than enough reason to be dissatisfied. Brueggemann (2014:90) fittingly articulated the situation of those in exile and those left behind in Jerusalem by saying:

The scene shifts from an emotional sense of well-being to one of loss, from a political sense of guarantee, to one of acute vulnerability, from a theological sense of chosenness to one of abandonment... Now the scene shifts to a new generation, the ones who were either "left behind" and important in Jerusalem or the ones deported to the waters of Babylon to ponder, in weeping, their new situation.... The new context for faith was one of emotional, political, and theological freefall without a discernible bottom.

We can agree that the people of Judah have experienced challenging situations that resulted in loss, disappointment, pain, grief and trauma. Circumstances that made it exceedingly difficult for them, in the short term, to 'hear' the comforting and encouraging words from Yahweh, uttered by the prophet Isaiah.

\section{Suitable engagement of the prophet's message}

People, in general, read the second main section of Isaiah (40-55) to find solace in the hope and trust that the prophet proclaims to the people of Judah. However, we often miss the subtext of suffering, pain, humiliation and sentiments of being neglected by Yahweh. In this regard, we are encouraged 'to hear those voices of pain and acknowledge the wreckage of dejected communities stripped of power, prestige and purpose' (Stulman \& Kim 2010:54).

Christians and people of faith should learn from these events. The losses people experienced are real and should be acknowledged and not ignored, because it makes them uncomfortable. At times, judgement is quick, and people are rebuked for lack of faith and of being disobedient to God. Grief, because of loss, is not a sign of weakness.

Grieving is a normal response to loss and in the process of grieving lives are transformed. For some, this period of transformation is overwhelming and they require help and support to manage their feelings. (Mallon 2008:1)
We should acknowledge expressions of frustration, anger, dismay and even rebellion, as real emotions that accompany loss and grief. Clergy can play a positive role in support of people, who have experienced loss of various kinds- and so can ordinary people- by rendering support and care. It is a different matter when clinical support is needed. It is the work of highly skilled therapists to deal with the various forms of loss and grief, especially with complicated grief, where it seems that a person is not making any progress to recovery, but is stuck in their grief or experience prolonged grief (McCoyd \& Walter 2016:4-5, 290-291).

There are many theories and models therapists use in dealing with loss and grief (McCoyd \& Walter 2016:8-18). People go through different phases in the process of working through loss and grief, to arrive at a stage of healing, reorganisation and meaning reconstruction (Hall 2014:10). It should, however, be emphasised that the process to move to recovery is not a linear one (McCoyd \& Walter 2016:11) and no two persons necessarily respond in a similar fashion or can be boxed into a predicted model of response. There are manifold trajectories through grief and grief is an extremely personalised experience (Hall 2014:8). Acknowledging the fact that people respond differently to loss and grief, as the clinical specialist has indicated, should caution us as people, who merely render support, to allow people space, in a nonjudgemental manner, to process losses and ensuing grief.

The words of encouragement, hope and trust uttered by the prophet about Yahweh, are real and true, but, whilst experiencing raw emotions, people are not always ready or in an emotional space to positively respond to them. Whilst the people were in Babylon, their captors mockingly requested the Judeans to sing one of the songs of Zion (Ahn 2008:280), to which they replied: 'How can we sing the Lord's song in a foreign land?' (Ps 137:4 NRS). It is unreasonable to expect of people, who are grieving their losses, to sing songs- the Judeans, instead, hung up their harps on the poplars (Viviers 2010:5). In the book of Lamentations, we find expressions of lament, because of what happened to Jerusalem and its people, because of the Babylonian invasion, destruction and exile (Westermann 1974:31). Loss causes trauma and grief, as well as denial, which can cause even more trauma (Snow et al. 2011:130-142). If this is the case, should the prophets stop speaking? Should we stop encouraging people or stop speaking of hope and healing?

\section{Prophets do what prophets have to do}

Prophets are intermediaries and intercessors between Yahweh and his people (Chalmers 2015:18-19). What they hear from God, they convey to his people (Nogalski 2015:3235). They are called, sent and have to speak his words of reprimand, rebuke and encouragement (cf. Jr 1; 29:19; Chalmers 2015:13-15). Micah 3 makes it clear that true prophets do not speak what people want to hear, but what they understand Yahweh wants them to communicate. They communicate words to the people that will have an effect on 
their future (Nogalski 2015:7). They communicate what they believe are life-changing messages from Yahweh. It is not that prophets like Isaiah and Jeremiah are tone-deaf to the cries and suffering of the people. Isaiah 40:1-2 is evidence that note is taken of the suffering of the people caused by the Babylonian exile, in the words underscoring that comfort is needed ('comfort, comfort my people') and also the words 'speak tenderly'. However, it is the obligation of the prophets to address the realities of the day and create trust in Yahweh. McEntire (2015:86) remarked in this regard: 'The book of Isaiah is moving towards an important transition from the pains of captivity to the struggles of freedom'. When people, for reasons of their circumstances, are not able to see light from day, prophets are the voices of reason and hope (Brueggemann 2014:119). As Nogalski (2015:102-103) said, and I quote, 'In fact, the themes of hope, restoration, and promise essentially functions as counter themes to the images of judgment that appear within the prophetic writings'. In the case of Isaiah 40:27, where the people of Judah voiced their complaint that Yahweh has abandoned them, whilst they are in exile, the prophet responds with these words in Isaiah 40:

${ }^{28}$ Have you not known? Have you not heard? The LORD is the everlasting God, the Creator of the ends of the earth. He does not faint or grow weary; his understanding is unsearchable.

${ }^{29} \mathrm{He}$ gives power to the faint, and strengthens the powerless.

${ }^{30}$ Even youths will faint and be weary, and the young will fall exhausted;

${ }^{31}$ but those who wait for the LORD shall renew their strength, they shall mount up with wings like eagles, they shall run and not be weary, they shall walk and not faint. (NRS)

Herein lies the hope for people, the prophet brings the perspective of who Yahweh is (cf.40:12-26) and how he will respond to doubt and loss. He is there for those who are weak and weary and feel despondent.

I have also mentioned Isaiah 49:14, where Zion, a reference to the people of the Judah, is quoted as saying: 'The LORD has forsaken me, the Lord has forgotten me' (Is 49:14 NIV). The two verbs 'forsake' (Qal עזב) and 'forget'(Qal שכח), in this context, express strong words of reproach of Yahweh. This type of language ties in with Westermann's (1969:219) view that verse 14 is an introduction to a communal lament. The wording, in verse 14, conveys strong honest emotions of the people in their unfavourable situation. What follows in the next verses is a dispute by Yahweh of these lamenting claims. The prophet, as spokesperson of Yahweh, responds to these allegations with two striking images, in verses 15-16:

Can a woman forget her nursing child, or show no compassion for the child of her womb? Even these may forget, yet I will not forget you. See, I have inscribed you on the on the palms of my hands. (NRS)

The unlikelihood that a mother will forget her child is trumped by the assertion that it is not even a thought to be entertained by the people of Judah. The promise is that Zion-
Jerusalem will get her children back (Goldingay \& Payne 2006:181). Also, the image of the engraving on Yahweh's hand emphasises both the permanency of such engraving and the visibility of hand, at all times. The engraving symbolises intimacy and closeness (Oswalt 1998:306). These images highlight Yahweh's faithfulness (Westermann 1969:220)

These two images are but two powerful examples; there are numerous others in the book of Isaiah that has the purpose of the prophet encouraging the people to put their trust in Yahweh, their faithful and loyal God.

\section{Conclusion}

It is not a matter of denial of the loss, pain and trauma experienced by the people and an insensitive bombardment with statement of faith in Yahweh by the prophets. From a pastoral point of view, both the aspects of venting emotions of discontent and words of comfort are valid and have a place. It is necessary to validate feelings of loss, pain, grief and the reality of trauma. To deny the reality of these feelings and experiences, both by the person who is the victim, as well as those who are in their circle of influence, is harmful and may have negative biological and psychological consequences (McCoyd \& Walter 2016:3-7). For the process of healing to take place and for personal growth, it is important to acknowledge these feelings. Time is of the essence for healing and growth to take place. Room should be allowed for the process to progress at its own pace. Mallon (2008) observed that:

Death and loss can act as a catalyst for spiritual development by leading the person, either to develop a new spiritual or religious path, or return to a known one but with greater depth and commitment. Belief in God may bring comfort when it cannot be found elsewhere. (p. 82)

At the same time, the prophetic words of encouragement and hope should be communicated and heard. They are important aspects in the healing process and to grow in faith and strength, to work through the troublesome experiences. The people of Judah needed to hear the prophetic words for them not to get stuck in their undesirable and painful situation, both physically and mentally. It might take time to be mentally ready to ponder on these prophetic words and renew their faith and hope in Yahweh, who will see to their future as his people.

The challenges of COVID-19 are real, uncomfortable and, in many instances, have heart-breaking consequences. But the prophetic words of encouragement and hope are also real and worth hearing and experiencing in these times of traumatic grief and loss.

\section{Acknowledgements}

This article is dedicated to Professor Stephan Joubert, a scholar who has the gift of successfully bridging the divide between the academic and public spaces. 


\section{Competing interests}

The author declares that he has no financial or personal relationships that may have inappropriately influenced him in writing this article.

\section{Authors' contributions}

W.J.W. is the sole author of this research article.

\section{Ethical considerations}

This article followed all ethical standards for research without direct contact with human or animal subjects.

\section{Funding information}

This research received no specific grant from any funding agency in public, commercial or not-for-profit sectors.

\section{Data availability}

Data sharing is not applicable to this article as no new data were created or analysed in this study.

\section{Disclaimer}

The views and opinions expressed in this article are those of the author and do not necessarily reflect the official policy or position of any affiliated agency of the author.

\section{References}

Ahn, J.J., 2008, 'Psalm 137: Complex communal laments', Journal of Biblical Literature 127(2), 267-289. https://doi.org/10.2307/25610120

Barker, M., 2003, 'Isaiah', in J.D.G. Dunn \& J.W. Rogerson (eds.), Eerdmans Commentary on the Bible, pp. 489-542, Eerdmans, Grand Rapids, MI.

Barro, R.J., Ursúa, J.F. \& Weng, J., 2020, 'The coronavirus and the great influenza pandemic: Lessons from the "Spanish Flu" forthe coronavirus's potential effects on mortality and economic activity', Cambridge, MA, viewed 05 December 2020, from http://www.neber.org/papers/w26866.

Berges, U., 2012, The book of Isaiah: Its composition and final form, Hebrew Bible Monographs, Sheffield Phoenix Press, Sheffield.

Blenkinsopp, J., 2002, Isaiah 40-55: A new translation with introduction and commentary, Doubleday, New York, NY.

Boda, M.J., Ames, F.R., Ahn, J.J. \& Leuchter, M. (eds.), 2015, The prophets speak on forced migration, SBL Press, Atlanta, GA.
Brueggemann, W., 2010, Out of Babylon, Abingdon Press, Nashville, TN.

Brueggemann, W., 2014, Reality, grief, hope: Three urgent prophetic tasks, Eerdmans, Grand Rapids, Ml.

Chalmers, A., 2015, Interpreting the prophets: Reading, understanding and preaching from the worlds of the prophets, IVP Academic, Downers Grove, IL.

Cronjé, F. \& Mullins, A., 2011, Water in die woestyn: Jesaja 28-39 : vier eeue saam met Jesaja, Biblaridion, Wierdapark.

Frissa, S. \& Dessalegn, B.S., 2020, 'The mental health impact of the COVID-19 pandemic: Implications for sub-Saharan Africa', viewed 27 February 2021, from https://doi.org/10.31219/osf.io/yq9kn.

Giliomee, H., 2012, Die Afrikaners: ' $n$ Biografie., 5de edn., Tafelberg, Kaapstad.

Goldingay, J., 2014, The theology of the book of Isaiah, IVP Academic, Downers Grove, IL.

Goldingay, J. \& Payne, D.F., 2006, A critical and exegetical commentary on Isaiah 40-55, T \& T Clark, London.

Hall, C., 2014, 'Bereavement theory: Recent developments in our understanding of grief and bereavement', Bereavement Care 3(1), 7-12. https://doi.org/10.1080/0 2682621.2014.902610

Jain, R., Budlender, J., Zizzamia, R. \& Bassier, I., 2020, 'The labor market and poverty impacts of covid-19 in South Africa', South Africa Labour and Development
Research Unit, Working Paper Series 264(1), 1-43, viewed 27 February 2021, from Research Unit, Working Paper
www.opensaldru.uct.ac.za.

Lim, B.H., 2010, The 'way of the Lord' in the book of Isaiah, T \& T Clark, London.

Mallon, B., 2008, Dying, death and grief: Working with adult bereavement, SAGE, London.

McCoyd, J.L.M. \& Walter, C.A., 2016, Grief and loss across the lifespan: A biopsychosocial perspective, 2nd edn., Springer Publishing Company, New York, NY.

McEntire, M.H., 2015, A chorus of prophetic voices: Introducing the prophetic literature of ancient Israel, Westminster John Knox, Louisville, KY.

Naidu, T., 2020, 'The COVid-19 pandemic in South Africa', Psychological Trauma: Theory, Research, Practice, and Policy 12(5), 559-561. https://doi.org/10.1037/ tra0000812

Nelson, R.D., 2014, Historical roots of the Old Testament (1200-63 BCE), SBL, Atlanta, GA.

Nogalski, J., 2015, Interpreting prophetic literature: Historical and exegetical tools for reading the prophets, Westminster John Knox, Louisville, KY.

Oswalt, J., 1998, The book of Isaiah. Chapters 40-66, Eerdmans, Grand Rapids, MI.

Petersen, D.L., 2015, 'Prophetic rhetoric and exile', in M.J. Boda, F.R Ames, J.J. Ahn, \& M.Leuchter (eds.), The prophets speak on forced migration, pp. 9-18, SBL Press, Atlanta, GA.

Sharp, C.J., 2019, The prophetic literature, Abingdon Press, Nashville, TN.

Snow, K.N., McMinn, M.R., Bufford, R.K. \& Brendlinger, I.A., 2011, 'Resolving anger towards God: Lament as an avenue towards attachment', Journal of Psychology and Theology 39(2), 130-142. https://doi.org/10.1177/009164711103900204

Stulman, L. \& Kim, H.C.P., 2010, You are my people: An introduction to prophetic literature, Abingdon Press, Nashville, TN.

Thompson, J.A., 1980, The book of Jeremiah, Eerdmans, Grand Rapids, MI.

Tull, P.K., 2010, Isaiah 1-39, Smyth \& Helwys, Macon, GA.

Viviers, H., 2010, 'Psalm 137: Perspectives on the (neuro-) psychology of loss', Verbum et Ecclesia 31(1), 1-7. https://doi.org/10.4102/ve.v31i1.397

Westermann, C., 1969, Isaiah 40-66, SCM, London.

Westermann, C., 1974, 'The role of the lament in the theology of the Old Testament', Interpretation 28(1), 20-38. https://doi.org/10.1177/002096437402800102 